\title{
Images of health
}

\section{The fine art of patient-doctor relationships}

\author{
M P Park, R H R Park \\ Paintings depicting patient-doctor relationships have been created for different reasons-among \\ them gestures of gratitude and as a form of therapy
}

\begin{abstract}
At Christmas many doctors experience brief but well intentioned and tangible gestures of successful patientdoctor relationships. Various patients' gifts, such as boxes of chocolates or bottles of wine, are always appreciated by the recipient. Although doctors may receive more permanent gifts, very few will have had the delight of having their portrait painted by their patient. Artists from different ages and cultures-Goya, Kahlo, Bellany, Van Gogh, Munch, and Dadd-have all had the desire to record their special relationship with their doctors.
\end{abstract}

\section{Goya and Dr Arrieta}

The Spanish artist Francisco Goya (1746-1828) has left the most moving testimony of his gratitude for the close relationship with his doctor in Self Portrait with $\mathrm{Dr}$ Arrieta (1820) (fig 1). In Seville, in the autumn of 1792, Goya developed a sudden serious illness which included dizziness, weakness, delirium, sickness, abdominal pain, deafness, and partial blindness. ${ }^{12}$ The name of his doctor has not been recorded. $\mathrm{He}$ convalesced in Cadiz, where in March 1793 his friend Sebastian Martinez reported: "Goya is slightly better but progress is sadly slow. The noises in his head and his deafness have not passed away; however, his sight has improved and he no longer has fits of dizziness and can walk up and down stairs without difficulty." On his return to Madrid in July 1793 Goya was completely deaf. Various diagnoses of this serious illness have been offered: syphilis, lead poisoning, cerebrovascular disease, acute infection of the central nervous system, and the rare condition of Vogt-Koyanagi-Harada syndrome- temporary inflammation of the uveal tract associated with permanent deafness. ${ }^{2}$

In 1819 Goya had a second serious illness. Little information is available either on the nature of the illness or on Dr Arrieta's treatment. The painting is the main source, and an inscription below the figures explains why Goya made the picture: "Goya, in gratitude to his friend Arrieta: for the compassion and care with which he saved his life during the acute and dangerous illness he suffered towards the end of the year 1819 in his seventy-third year. He painted this in 1820."

Goya had recently finished a commission for The Last Communion of San José de Calasanz in the church of San Antonio Abad in Madrid. Although this theme may have inspired the composition of the self portrait, with Arrieta in the role of the priest administering to the dying soul, there is a fundamental difference: San José is resigned to death whereas Goya grasps his bedsheet as if clinging on to life and is supported from falling backwards by the arm of Arrieta. As the doctor gently encourages his patient to take the medicine, shadowy figures-perhaps his servants and a priest-in the background seem to be portents of doom. Goya may have expected to die, but under Arrieta's care, he was nursed back to health and lived another eight years.

In 1819 Goya had moved out of the centre of Madrid to the Quinta del Sordo (House of the Deaf Man) and on his recovery decorated the walls with a series of "black paintings," including Saturn Devouring One of his Children, now in the Prado. These are dark,

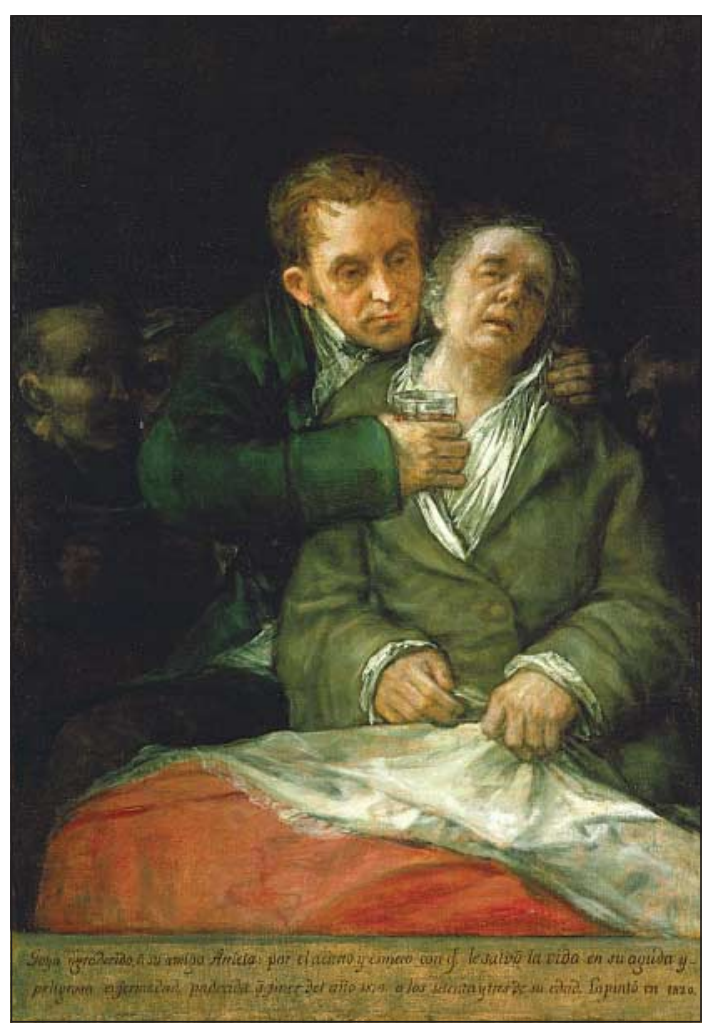

Fig 1 Goya's Self Portrait with Dr Arrieta, 1820. Minneapolis Institute of Arts, The Ethel Morrison Derlip Fund
Department of Adult and Continuing Education,

University of Glasgow, Glasgow G3 6NH

M P Park lecturer in history of art

Southern General Hospital, Glasgow G51 4TF

R H R Park consultant gastroenterologist Correspondence to: M P Park mpark@educ.gla.ac.uk BMJ 2004;329:1475-80 


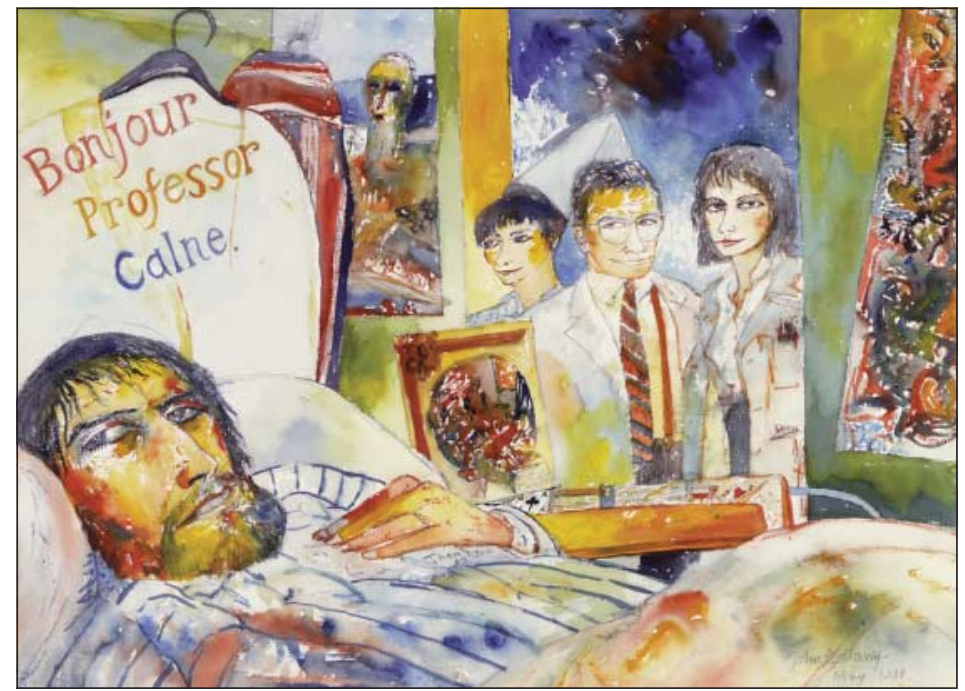

Fig 2 Bellany's Bonjour Professor Calne, 1988. Aberdeen Art Gallery and Museums Collections
Gustave Courbet's painting Bonjour, Monsieur Courbet (1854), in which the proud and healthy looking artist, on the road to Montpellier, is met by his patron and a servant. Bellany has transformed the idea into a hospital scene. He lies in his hospital bed, weak from surgery, staring out at us while behind him stand members of the medical team: his "patron" Sir Roy Calne, Dr Jacobson, and a nurse. Above his head are the words "Bonjour Professor Calne" and under his hand is the inscription: "Thank you All." On a table lie playing cards and a book, Confessions of An Unjustified Sinner, reminders perhaps of his past life. Like Goya's picture, this is an image of hope: the medical team smiles out at us and the colours are remarkably vivid and less strident than in his paintings before the operation, a reflection of the new lease of life Bellany was already beginning to appreciate.

Sir Roy Calne had produced paintings before he encountered Bellany. Their friendship, however, inspired him to pursue that interest and since 1991 he has exhibited many paintings and sculptures relating to transplantation. ${ }^{5}$ For Bellany, his operation was a turning point in his artistic development. His recent paintings, exhibited widely to celebrate his 60th birthday, are a celebration of life. His Addenbrooke's Hospital portraits functioned both as gestures of gratitude to his medical carers and as therapeutic aids to improve his recovery.

\section{Van Gogh and Drs Cavenaille, Rey, and Gachet}

Several diagnoses-bipolar disorder, alcoholism, acute intermittent porphyria triggered by absinthe abuse, and sexually transmitted diseases-have been offered to explain Vincent van Gogh's complex medical history. ${ }^{67}$ As a result of his recurrent illnesses he had many encounters with the medical profession, and by the time of his death in 1890 he had painted three doctors.

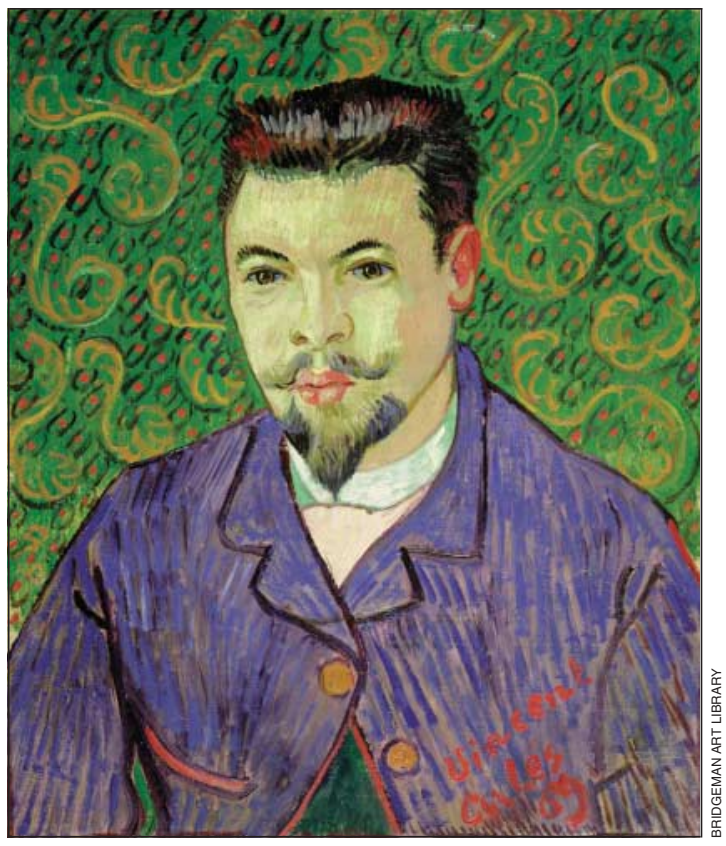

Fig 3 Van Gogh's Portrait of Félix Rey, 1889. Pushkin Museum, Moscow 
In 1886, while staying in Antwerp, Van Gogh consulted Dr Hubertus Amadeus Cavenaille for treatment for dyspepsia and probable syphilis. Van Gogh informed Dr Cavenaille that he had no money but that he would paint his portrait, which subsequently has been lost. ${ }^{8}$ In February 1888 Van Gogh left Paris and settled in Arles, where he hoped to recover his health (he admitted to Gauguin that he was nearly an alcoholic) and establish an artists' colony. After an argument with Gauguin on 24 December 1888, Van Gogh cut off the lower lobe of his left ear and was admitted to the hospital in Arles.

Van Gogh was very impressed with the house surgeon, Dr Félix Rey (1867-1932), and wrote to his brother Theo, "If ever you want to make the house surgeon Rey very happy, this is what would please him hugely. He has heard of a picture by Rembrandt, the 'Anatomy Lesson'. I told him that we would get him the engraving after it for his study. As soon as I feel somewhat up to it, I hope to do his portrait." ${ }^{\prime 9}$ Ten days after leaving hospital, in January 1889, Van Gogh started work on the Portrait of Félix Rey (fig 3). It is one of Van Gogh's most charming portraits: Dr Rey looks directly out at the viewer, his features clearly defined in small, controlled brushstrokes, a technique that was influenced by Gauguin. Only the swirl motifs in the background hint at the emotional crisis Van Gogh had so recently experienced. He painted Dr Rey's portrait in gratitude for the sympathetic treatment he had received and gave it to the doctor. It would seem that Dr Rey may have appreciated the gesture more than the painting itself, for tradition has it that he used it to block a hole in a chicken coop.

After spending a year in the Saint-Paul-de-Mausole Asylum at Saint-Rémy-de-Provence in May 1890, Van Gogh moved to Auvers-sur-Oise, near Paris. His brother Theo had arranged for Dr Paul Ferdinand Gachet (1828-1909), a specialist in nervous diseases and homoeopathy, to supervise his care. In the 1870 s Gachet had befriended and supported some of the Impressionists, including Pissarro and the young Cézanne. Dr Gachet shared Van Gogh's love of art: "I have found a true friend in Dr Gachet, something like another brother, so much do we resemble each other physically and also mentally. He is a very nervous man himself and very queer in his behaviour." had been interested in the role of occupational therapy in the management of psychiatric disorders, and he encouraged Van Gogh to paint, as Van Gogh mentioned in a letter to his mother: "He tells me that in my case work is the best thing to keep my balance."

During the 70 days he spent at Auvers-sur-Oise before his death on 29 July 1890, Van Gogh portrayed Dr Gachet in one sketch, an etching, and two oil paintings as well as painting Gachet's daughter Marguerite. Dr Gachet encouraged Van Gogh to experiment with etching, and within five days of his arrival in Arles in May he had produced his first and only etchingLHomme à la Pipe, Dr Gachet-using Gachet's printing press (fig 4). Gachet's son has recorded that "After lunch in the open air in the courtyard, and with their pipes lit, Vincent was given an etching needle and a prepared copper plate, and accepted with enthusiasm that his new friend should be the motif." 10

In a letter to his brother Theo dated 4 June 1890, Van Gogh writes of working on a painted portrait of

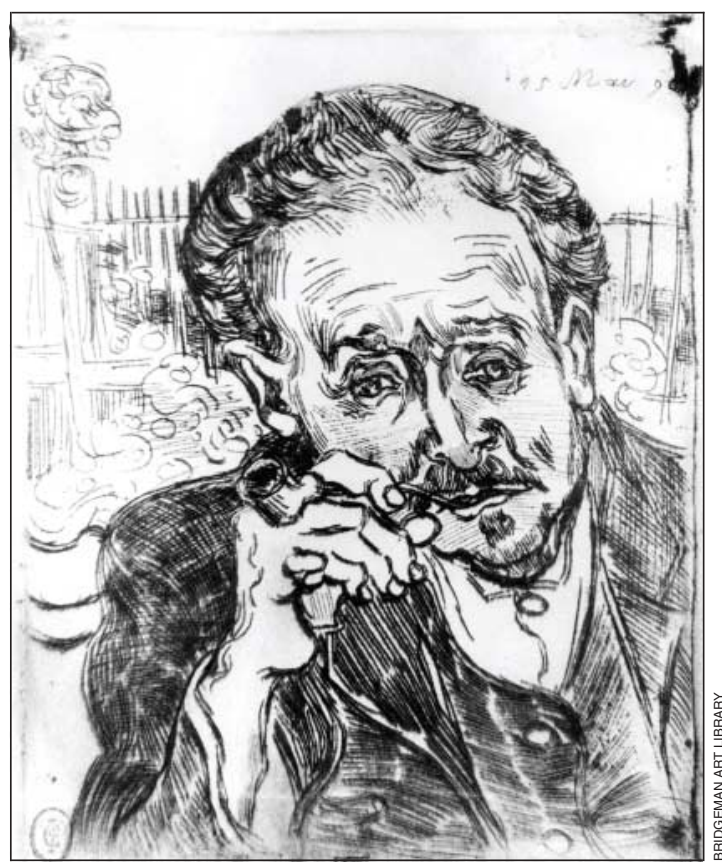

Fig 4 Van Gogh's L'Homme à la Pipe, Dr Gachet, 1890. Bibliotheque Nationale Paris

Gachet. "M. Gachet is absolutely fanatical about this portrait, and wants me to do one for him, if I can, exactly like it." "The first version is in a private collection and represents the doctor seated, his arm resting on a table on which are seen two books, Manette Salomon and Germinie Lacerteux by Edmond and Jules de Goncourt, and foxgloves in a vase; the second, which omits the books and has the foxgloves resting on the table, is in the Musée d'Orsay, Paris. The foxgloves were a reference both to Dr Gachet's late wife, who had been fond of the flowers, and to their medicinal qualities. Both versions convey most powerfully the "expression of melancholy" mentioned by Van Gogh. ${ }^{9}$ Their friendship was cut short by death. On 27 July, Van Gogh shot himself in the chest. Gachet wrote immediately to summon Theo. Van Gogh died two days later, in his brother's arms. Gachet made a small sketch of the artist on his deathbed and was one of the few mourners to walk with Theo at Van Gogh's funeral.

\section{Munch and Dr Jacobsen}

The Norwegian artist Edvard Munch (1863-1944) entered the Copenhagen psychiatric clinic of Dr Daniel Jacobsen on 3 October 1908. His admission was the result of many years of deteriorating mental health: depression with paranoia, aggravated by alcoholism. ${ }^{11}$ During his eight month recuperation at the clinic, he sketched himself receiving "electrification" (nonconvulsive electrotherapy ${ }^{12}$ ) from Jacobsen and his assistant, Miss Schacke (fig 5). ${ }^{13}$ Above the sketch Munch wrote: "Professor Jacobsen is electrifying the famous painter Munch, and is bringing a positive masculine force and a negative feminine force to his fragile brain."

Munch also produced The Nurse, a drypoint engraving of Miss Schacke in profile, and three portraits of Jacobsen, two in full length (fig 6). Jacobsen's pose is derived from the full length portrait 


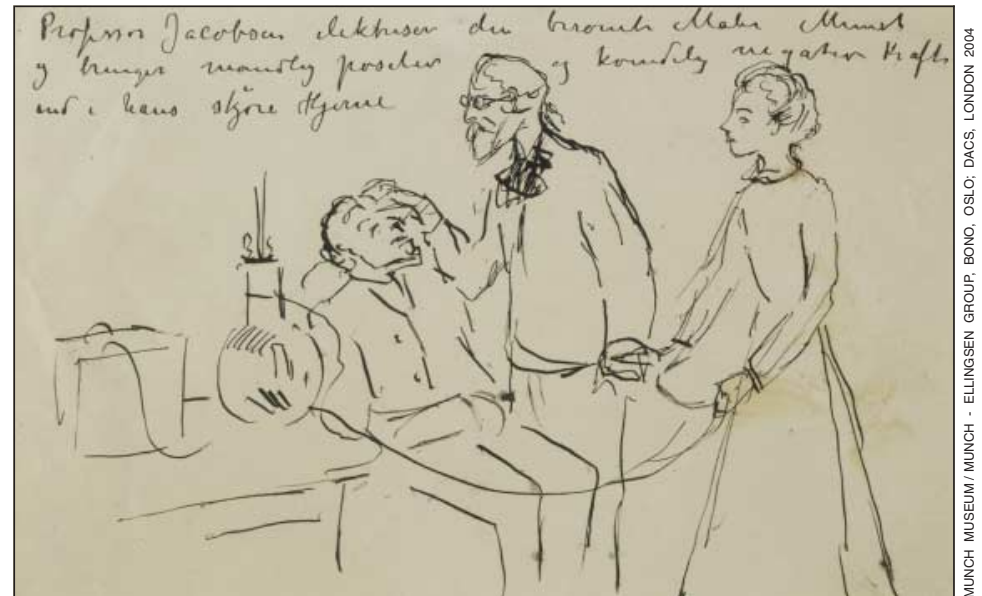

Fig 5 Munch's Dr Jacobsen electrifying Munch, 1908-9. Munch Museum, Oslo

of King Henry VIII by Holbein and conveys the same sense of power and authority. Munch later wrote, "Jacobsen was a fine physician. He walked around like a pope among white nurses and pale patients. The food was white too-everything was white except Jacobsen. I wanted to say something too, so I asked him to pose for me. I placed him in the picture, big and strutting in a fire of colour like all hell. Then he pleaded with me-became tame like a pigeon." 14 Although he acknowledged his need for the doctor's medical expertise, Munch resented his dependence on Jacobsen and sought refuge in his painting. "When I painted I was the master. I felt that I dominated him, who had dominated me." ${ }^{15}$

His health fully recovered, Munch left the clinic in 1909 and returned to Norway. These portraits seem to have been produced more for therapeutic reasons than as tokens of gratitude. He does not seem to have shared the same close relationship with his doctor as Goya and Kahlo. He did not continue any contact with Jacobsen, and 20 years later, on meeting Jacobsen by chance in the street, he almost failed to recognise him.

\section{Kahlo and Drs Eloesser and Farill}

Three paintings by the Mexican artist Frida Kahlo (1907-54) illustrate her relationships with two of her doctors. At the age of 6 she developed poliomyelitis, which weakened and deformed her right leg. ${ }^{16}$ In September 1925 she was involved in a bus accident, resulting in serious pelvic and spinal injuries which were to produce recurring ill health. During a visit to San Francisco in 1930 she developed problems with her right leg and consulted Dr Leo Eloesser (1881-1976), a pioneer of thoracic and orthopaedic surgery at San Francisco General Hospital, who was to become one of her lifelong medical advisers. ${ }^{17}$ Kahlo showed her gratitude in two paintings, Portrait of Dr Eloesser (1931) and in 1940, after consulting him for back pain and a fungal infection of her right hand, in the Self Portrait Dedicated to Dr Eloesser. In his portrait he stands rather awkwardly in a corner of a room, leaning against a table on which is placed a model sailboat, a reference to the yacht he sailed in San Francisco Bay. He seems to be a rather stiff and aloof character. Any sense of distance in the relationship between doctor and patient, however, is dispelled in her Self Portrait
Dedicated to Dr Eloesser. The dedication in the banderole at the bottom states: "I painted my portrait in the year 1940 for Dr Leo Eloesser my doctor and my friend. With all love, Frida Kahlo." This votive-like portrait is similar to Goya's Self Portrait with Dr Arrieta in its emphasis on personal suffering. Round her neck Kahlo wears a circlet of thorns which is cutting into her skin and causing her to bleed, a reminder of the constant physical pain she was forced to endure throughout her adult life.

Self Portrait with the Portrait of Dr Farill (1951) was completed after a prolonged period of ill health. ${ }^{18}$ Kahlo had spent nine months in the ABC Hospital in Mexico City undergoing seven orthopaedic operations complicated by infected bone grafts. The painting is dedicated to her orthopaedic surgeon: "Dr Juan Farill saved me. He gave me back my joy in life. I am still in a wheelchair and I don't know how soon I will be able to walk again... I have already begun the little painting that I am going to give to Doctor Farill and that I am doing with all my affection for him." ${ }^{17}$ She depicts herself in her wheelchair, sitting beside her easel, on which is propped the painted portrait of the doctor, his head turned towards her as if watching over her. In one hand she holds a collection of brushes from which fall drops of red paint onto her white robe; in the other she holds her artist's palette, transformed into an image of her heart. The brushes and palette are considered symbols

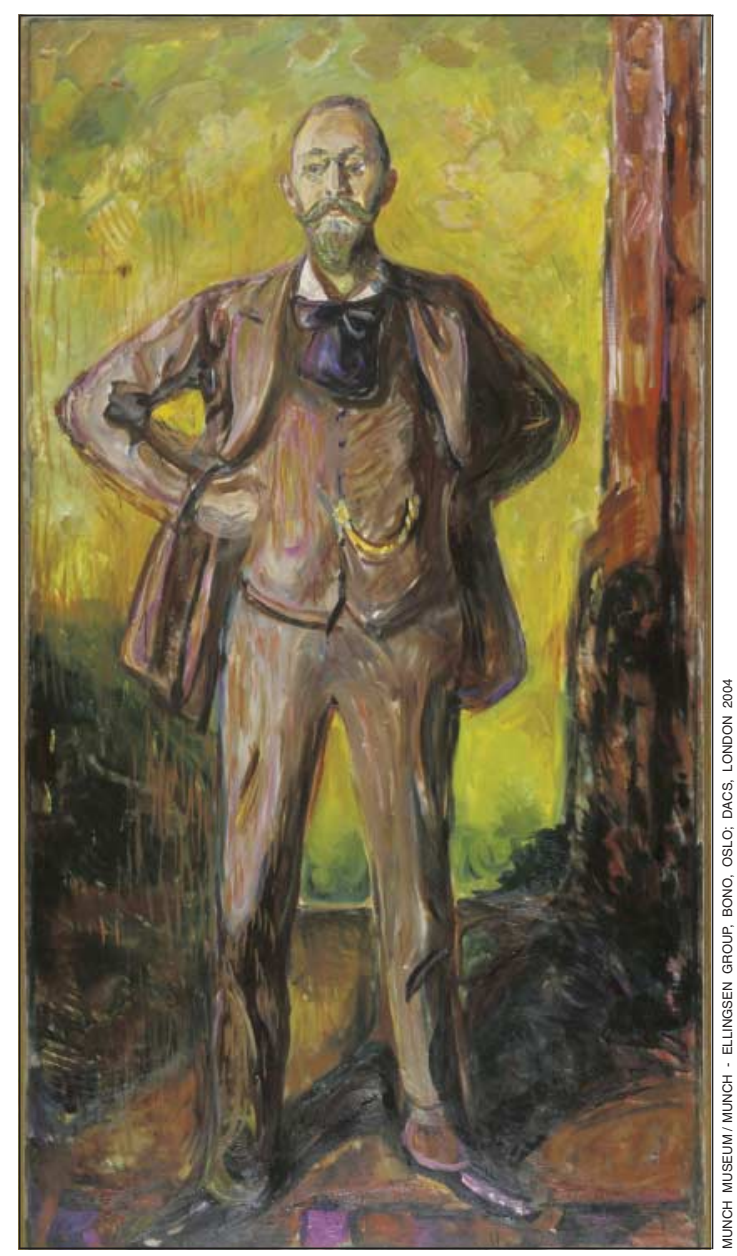

Fig 6 Munch's Portrait of Dr Jacobsen, 1909. Munch Museum, Oslo 
of her suffering. Art and medicine are truly combined in this most personal of self portraits.

\section{Dadd and Drs Morison, Orange, and Hood}

Less well known is the close relationship between the English painter Richard Dadd (1817-86) and the medical staff who treated him during his 42 year confinement in Bethlem and Broadmoor Hospitals. ${ }^{19}$ Dadd was on an extensive tour of Egypt and the Holy Land in 1842-3 when, apparently suffering from exhaustion and sunstroke, he first showed signs of mental illness. In November 1842 he wrote to the artist William Powell Frith of his experiences: "At times the excitement of these scenes has been enough to turn the brain of an ordinary weak-minded person like myself, and often I have lain down at night with my imagination so full of wild vagaries that I have really and truly doubted my own sanity." ${ }^{\prime 20} \mathrm{He}$ believed that spirits were chasing him and became violent and unpredictable in his behaviour.

On his return home, Dadd seemed to recover. His father ignored the advice of Dr Alexander Sutherland, physician of St Luke's Asylum, to have his son put under restraint. Instead, on 28 August 1843 he accompanied his son on a visit to Cobham Park in Kent where Dadd, believing his father to be the devil, used a razor and a knife to kill him. He fled to France but was quickly apprehended and temporarily placed in Clermont Asylum. After committal proceedings he was moved to the Criminal Lunatic Department of Bethlem Hospital on 22 August 1844. Though the medical notes are scanty, the diagnosis is considered to be schizophrenia. $^{21}$

Dadd was extremely fortunate in the medical care he received at Bethlem. He was encouraged to paint during periods of sanity, and materials were provided for his use. Much of his artwork done in confinement has survived, including his most celebrated painting The Fairy Feller's Master-Stroke (painted between 1855 and 1864, now in the Tate Gallery), which was a gift to G H Haydon, the steward of Bethlem Hospital. Dadd also painted portraits of several members of the hospital staff, among them Sir Alexander Morison, visiting consultant physician at Bethlem; Dr William Orange, superintendent of Broadmoor; and possibly Dr William Charles Hood, the first resident physician superintendent of Bethlem.

A pioneer of psychiatric medicine, Alexander Morison (1779-1866) published his Physiognomy of Mental Diseases in 1838, three years after his appointment to Bethlem. Morison's diaries reveal that he collected drawings by Dadd during his time at Bethlem. He may have commissioned Portrait of Sir Alexander Morison (fig 7) to commemorate his departure from Bethlem in 1852. Dadd presents Morison standing in the foreground, looking out towards us, with a view of his estate in Anchorfield, Newhaven, behind. Morison's daughter Ann had provided a sketch of the family home for Dadd's use. The picture also includes two Newhaven fishwives, perhaps inspired by the famous series of pioneering photographs by Hill and Adamson. The portrait is eerily disquieting: Morison shows no emotion and seems remote from his surroundings, although this sense of alienation may

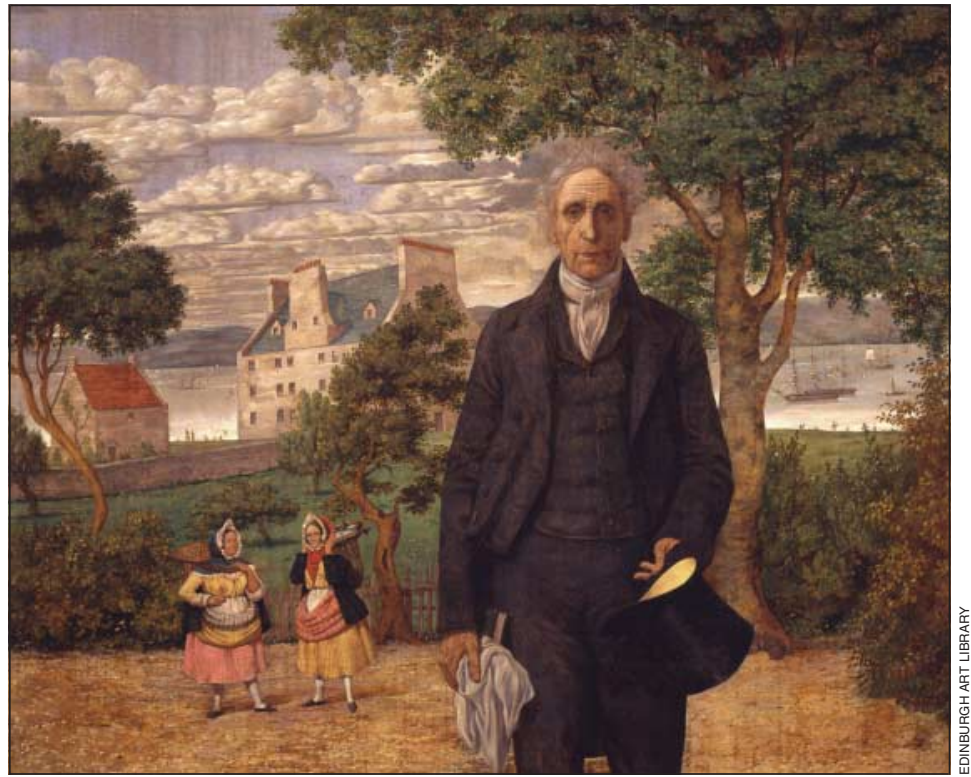

Fig 7 Dadd's Portrait of Sir Alexander Morison, 1852. Scottish National Portrait Gallery, Edinburgh

reflect Dadd's state of mind rather than Morison's own character.

Although identification remains uncertain, Dadd's 1853 Portrait of a Young Man may represent Dr William Charles Hood (1824-70). The sitter is placed directly facing us on an elaborate wooden bench, his hands folded in his lap, and his head framed by the leaves of a huge sunflower. The red fez cap and a white handkerchief beside him are items relating to Dadd's travels in the Middle East. It is a remarkable image, combining realistic portraiture within an imaginary landscape. In his case notes of 1854, Hood records Dadd's sporadic violent outbursts while describing him as "a very sensible and agreeable companion, and shew in conversation, a mind once well educated and thoroughly informed in all the particulars of his profession in which he still shines." ${ }^{19}$ The sale of Hood's property after his death included 33 works by Dadd.

In 1864 Dadd was moved to Broadmoor Hospital, Berkshire, and continued to benefit from the friendship and patronage of the hospital staff. The 1875 Portrait of Dr William Orange is a traditional representation of the doctor, meticulously painted and more subdued in tone than Dadd's earlier portraits. Dadd painted murals for the Dr Orange's house in the early 1880 s as well as stage scenery for the hospital theatre. Dr Orange retired from his post in Broadmoor in 1886, the same year that Dadd died of tuberculosis.

\section{Mutual respect}

Patient-doctor relationships are generated by different behavioural patterns. Similarly, the art depicting these relationships is created for different reasons-as gestures of gratitude, for payment of medical fees, on commission, and as a form of therapy. In A Country Doctor Franz Kafka observed that "to write prescriptions is easy, but to come to an understanding of people is hard." The importance of mutual respect and trust in the patient-doctor relationship is nowhere better illustrated than in the portraits of their doctors by Goya and his fellow artists. 
Contributors and sources: MP and RP were joint curators of the Royal College of Physicians and Surgeons of Glasgow quatercentenary exhibition "The Fine Art of Medicine" held at the Hunterian Museum, Glasgow, in autumn 1999 and have been co-authors of articles exploring the relation between art, medicine, and health. Sources have included monographs on artists; gallery and exhibition catalogues; medical text books and journals.

Competing interests: None declared.

1 Foy JL. The deafness and madness of Goya. Conscious and unconscious expressive art. Vol 3. Basel: Karger, 1971.

2 Cawthorne C. Goya's illness. Proc Roy Soc Med 1962;55:213-7.

3 Licht F. Goya: the origins of the modern temper in art. New York: Harper and Row, 1983.

4 McEwan J. John Bellany. Edinburgh and London: Mainstream Publishing, 1994.

5 Groves T. The art of surgery. BMJ 1989;299:1576-7

Loftus LS, Arnold WN. Vincent van Gogh's illness: acute intermitten porphyria? BMJ 1991;303:1589-91.

7 Jamison KR, Wyatt RJ. Vincent van Gogh's illness. BMJ 1992;304:577.
8 Tralbaut ME. Vincent van Gogh. London: Macmillan, 1974

The complete letters of Vincent van Gogh. 2nd ed. London: Thames and Hudson, 1978.

10 Pickvance R. Van Gogh in Saint-Rémy and Auvers. New York: Metropolitan Museum of Art and Abrams, 1986

11 Viederman M. Edvard Munch: a life in art. J Am Acad Psychoanalysis 1994;22:73-110.

12 Stainbrook E. The use of electricity in psychiatric treatment during the nineteenth century. Bull Hist Med 1948;22:156-77.

13 Stang N. Edvard Munch. Oslo: Tanum,1972.

14 Stenersen R. Edvard Munch: close-up of a genius. Oslo: Gyldendal Norsk Forlag, 1969.

15 Heller R. Munch: his life and work. London: John Murray, 1984.

16 Herrera H. Frida: a biography of Frida Kahlo. London: Bloomsbury, 1989 17 Kettenmann A. Frida Kahlo: pain and passion. Köln: Benedikt Taschen, 1993.

18 Lomas D, Howell R. Medical imagery in the art of Frida Kahlo. BMJ 1989;299:1584-7.

19 Allderidge P. The late Richard Dadd. London: Tate Gallery, 1974.

20 Frith WP. My autobiography and reminiscences. London: Richard Bentley and Son, 1888.

21 Allderidge P. Richard Dadd (1817-1886): painter and patient. Med Hist 1970;14:308-13.

\section{Memories aren't made of this: amnesia at the movies}

\section{Sallie Baxendale}

Most amnesic conditions in films bear little relation to reality. Since movies both inform and reflect public opinion, doctors should be aware of the prevalent myths about amnesia. This could be invaluable when informing patients and their relatives of a diagnosis of an amnesic condition and its likely prognosis

Department of Neuropsychology, Box 37, National Hospital for Neurology and Neurosurgery, London

WC1N 3BG

Sallie Baxendale clinical neuropsychologist sallieb@ion.ucl.ac.uk BMJ 2004;329:1480-3

\section{Early cinema}

Hollywood's recent offerings, The Eternal Sunshine of the Spotless Mind (2004) and 50 First Dates (2004), head up a long tradition of movies featuring amnesic characters. No fewer than 10 silent movies (before 1926) do so. In

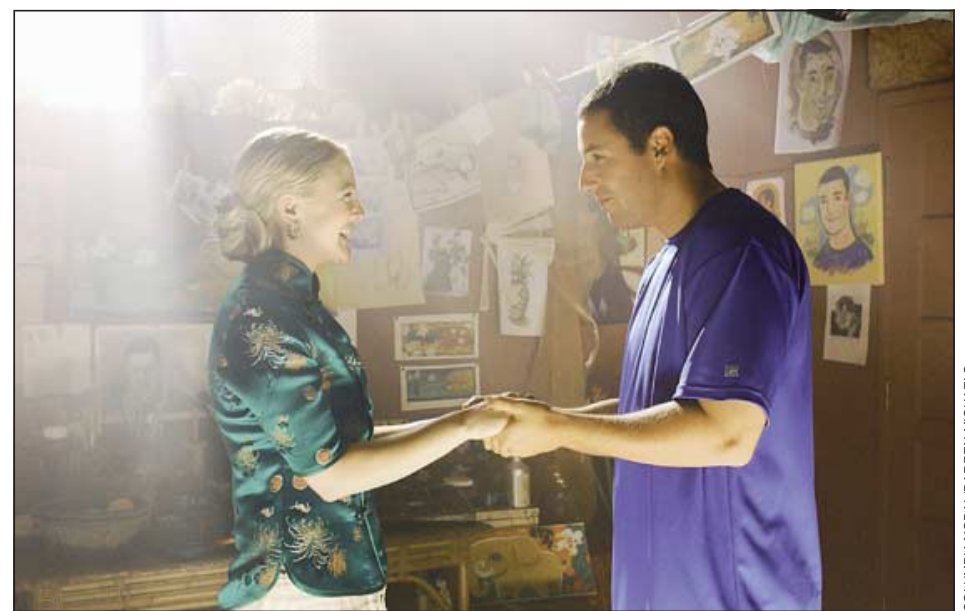

50 First Dates maintains a venerable movie tradition of portraying an amnesiac syndrome that bears no relation to any known neurological or psychiatric condition one of the earliest, Garden of Lies (1915), predictable complications ensue when a doctor hires a new husband for an amnesic bride in an attempt to jog her memory. This film was an early trendsetter, and nuptials have precipitated amnesia in later films (Samaya, 1975; Kisses for Breakfast, 1941). In 1915 The Right of Way was one of the first films to depict amnesia as the result of an assault, and the trigger for starting life afresh. These themes are seen again in The Victory of Conscience (1916) and have been consistently used throughout the decades to modern times (see Amateur,1994).

\section{Amnesic syndromes}

In the real world, most profound amnesic syndromes have a clear neurological or psychiatric basis. True dissociative amnesia or fugue states are rare, but people with such conditions are able to learn new information and perform everyday tasks in the context of a profound retrograde amnesia triggered by a traumatic event. The most commonly agreed features of organic amnesic syndromes include normal intelligence and attention span, with severe and permanent difficulties in taking in new information. Personality and identity are unaffected. These distinctions, which in a medical setting are critical in terms of prognosis and treatment, are often blurred at the movies.

The most profound amnesic syndromes usually develop as a result of neurosurgery, brain infection, or a stroke. These factors are overlooked at the movies in favour of the much more dramatic head injury. Road traffic crashes and assault are the most common causes

Details of the films mentioned in this article are listed on bmj.com 